\title{
НАУЧНЫЕ ДИСКУССИИ
}

\section{DOI: 10.19181/lsprr.2021.17.4.9 \\ БЕЗУСЛОВНЫЙ БАЗОВЫЙ ДОХОД КАК РЕГУЛЯТОР ПОВЫШЕНИЯ УРОВНЯ И КАЧЕСТВА ЖИЗНИ ГРАЖДАН И УСТОЙЧИВОСТИ ОБЩЕСТВА: ПРОБЛЕМЫ И ВОЗМОЖНЫЕ ПУТИ ИХ РЕШЕНИЯ Дискуссия на российско-германской международной конференции. Москва. 20 мая 2021 г.}

\author{
Тип статьи: научная \\ Получено 14.09.2021 Одобрено 13.10.2021 Опубликовано 03.12.2021
}

Для цитирования: Бобков В.Н., Одинцова Е.В., Пилюс А.Г. Безусловный базовый доход как регулятор повышения уровня и качества жизни граждан и устойчивости общества: проблемы и возможные пути их решения. Дискуссия на российско-германской международной конфреренции. Москва. 20 мая 2021 г. // Уровень жизни населения регионов России. 2021. Том 17. №4. C. 524-541. DOI: 10.19181//sprr.2021.17.4.9

\section{В.Н. БОБКОВ ${ }^{1,2}$, Е.В. ОДИнцОВА ${ }^{1,2}$, А.Г. пилюс ${ }^{3}$}

${ }^{1}$ ИСЭПН ФНИСЦ РАН (117218, Россия, Москва, Нахимовский проспект, 32).

${ }^{2}$ РЭУ им. Г.В. Плеханова (117997, Россия, Москва, Стремянный переулок, 36).

3 Фрайбургский университет им. Альберта и Людвига (79085, Германия, Фрайбург в Брайсгау, площадь Фаненберга).

\begin{abstract}
Аннотация
Статья раскрывает контуры международного дискурса по теоретическим и практическим проблемам концепции безусловного базового дохода через призму дискуссии, состоявшейся в мае 2021 г. в рамках Международной российско-германской научной конференции «Безусловный базовый доход как регулятор повышения уровня и качества жизни граждан и устойчивости общества: проблемы и возможные пути их решения». Авторами представлены дайджесты выступлений докладчиков, составившие научную основу статьи, посвящённой вопросам концептуализации феномена безусловного базового дохода (ББД), научному, политическому и государственному аспектам дискурса об имплементации ББД, проблемам внедрения ББД в переходных формах, практике экспериментального введения ББД, моделирования последствий внедрения ББД, влияния ББД на различные стороны жизни и др. Материалы состоявшейся международной конференции очерчивают основные проблемные контуры исследования концепции ББД и вопросов её внедрения, позволяя определить направления дальнейших разработок, среди важнейших из которых - поиск целесообразных страновых переходных форм ББД и инструментариев его экспериментальной апробации для повышения уровня и качества жизни и устойчивости общества. Дискуссия на конференции по вопросам концепции ББД прокомментирована в статье в контексте практических действий российских и германских органов власти, предложений международного научного сообщества и необходимости перехода к более масштабному и комплексному пилотированию ББД в русле идей, прозвучавших на международном Конгрессе Вазіс Income Earth Network (BIEN), прошедшем в августе 2021 г. в г. Глазго, Шотландия.
\end{abstract}

Ключевые слова: безусловный базовый доход, переходные формы, пилотные проекты, уровень жизни, качество жизни, устойчивость общества, научный дискурс

\section{Введение}

В августе 2021 г. состоялся очередной, 22-ой Конгресс Всемирной сети основных доходов (The Basic Income Earth Network, BIEN), который привлёк к участию более 1000 участников со всего мира и основная тема которого звучала как «От идеи к реальности». ${ }^{1}$ В рамках данного Конгресса был представлен и российский опыт исследований данной проблематики. Хотя для российского научно-экспертного сообщества исследования и практические шаги по введению безусловного базового дохода (ББД) являются сравнительно новыми, Россия вносит свой вклад в развитие международного дискурса. Во-первых, посредством публикаций исследований по проблематике ББД [например, 1 ; 5; 9; 12; 14], во-вторых, через открытые организованные дискуссии, с привлечением широкого круга специалистов, как российских, так и зарубежных. Одна из таких дискуссий состоялась 21 мая 2021 г. в РЭУ им. Г.В. Плеханова в рамках международной научной конференции «Безусловный базовый доход как регулятор повы-

BIEN-2021. Programme. URL: https://cbin.scot/wpcontent/uploads/2021/08/BIEN-2021-Programme-05-August. pdf (Accessed: 23.08.2021). шения уровня и качества жизни граждан и устойчивости общества: проблемы и возможные пути их решения».

Международная научная конференция была организована российскими и германскими учёными, занимающимися исследованием ББД. С российской стороны организатором выступил РЭУ им. Г.В. Плеханова (Научный центр экономики труда, Научная школа «Теория и технологии менеджмента»), с германской стороны - Фрайбургский университет им. Альберта и Людвига (г. Фрайбург, Германия). В организации конференции также принимали участие представители Института мировой экономики и международных отношений РАН (ИМЭМО РАН) и Института социально-экономических проблем народонаселения ФНИСЦ РАН (ИСЭПН ФНИСЦ РАН). Международная конференция привлекла к участию и дискуссии специалистов из Германии, Италии и России, включая представителей академического сообщества, Федерации Независимых Профсоюзов России (ФНПР) и Государственной Думы Федерального Собрания Российской Федерации. ${ }^{2}$

2 Официальный сайт РЭУ им. Г.В. Плеханова. URL: https:// www.rea.ru/ru/org/managements/Nauchnyjj-centr-ehkonomikitruda/Pages/news.aspx (дата обращения: 01.07.2021). 
Конференция была организована в рамках научного проекта № 20-010-00271 «Безусловный базовый доход как регулятор повышения уровня и качества жизни: теоретико-методологическое обоснование, переходные формы и инструментарий для тестирования в России», peaлизуемого при грантовой поддержке Российского фонда фундаментальных исследований под руководством д.э.Н., профессора В.Н. Бобкова.

В рамках конференции с докладами выступили представители РЭУ им. Г.В. Плеханова, ИСЭПН ФНИСЦ РАН, ИМЭМО РАН, Национального исследовательского Нижегородского государственного университета им. Н.И. Лобачевского (ННГУ), Фрайбургского университета им. Альберта и Людвига, Фрайбургского Института исследований базового дохода (FRIBIS). Отличительной особенностью конференции стал контекст сравнения предпосылок для внедрения ББД в России и Германии.

Объект статьи - безусловный базовый доход как концепция и инструментарий, предмет возможности для повышения уровня и качества жизни населения и устойчивости общества. Цель статьи заключалась в представлении научного (российского и зарубежного) поля дискуссий по вопросу о безусловном базовом доходе.

Исследовательская гипотеза состояла в том, что продолжение дискуссии по поводу потенциала безусловного базового дохода и связанных с его имплементацией проблем и последствий позволит внести вклад в продвижение к согласованной позиции, продвинуться от обсуждения идеи и концепции к более широкой реализации данного инструментария.

В основу статьи положены материалы (дайджесты), специально подготовленные участниками международной научной конференции «Безусловный базовый доход как регулятор повышения уровня и качества жизни граждан и устойчивости общества: проблемы и возможные пути их решения» по итогам выступлений с докладами в рамках конференции.

\section{Безусловный базовый доход как регулятор повышения уровня и качества жизни граждан и устойчивости общества: проблемы и пути их решения в позициях участников конференции}

Вячеслав Бобков, директор Научного центра экономики труда РЭУ им. Г.В. Плеханова, заведующий лабораторией проблем уровня и качества жизни ИСЭПН ФНИСЦ РАН, являвшийся модератором конференции, посвятил свой доклад концептуализации феномена ББД, его влиянию на различные стороны жизни, а также научному, потитическому и государственному аспектам дис- курса об имплементации ББД в России до и после начала пандемии COVID-19. ${ }^{3}$

В аспекте концепции ББД В. Бобковым был подчёркнут достигнутый среди исследователей консенсус по четырём его основным принципам:

- предназначение ББД для всех граждан (универсальность);

- ББД как основание, над которым формируются все другие источники доходов граждан (базовая часть дохода гражданина);

- выплата ББД независимо от занятости и других оснований жизнедеятельности (безусловность);

- регулярность выплаты (как альтернатива разовым выплатам).

По двум другим принципам, которые также артикулируются в концепции ББД, были аргументированы сомнения в целесообразности их отнесения к основным принципам:

- денежная форма выплаты. Это, по мнению В. Бобкова, вопрос дискуссионный: ББД может предоставляться не обязательно в денежной форме; для граждан он может доводиться и в форме бесплатных благ, позволяющих удовлетворять «корзину» базовых потребностей;

- индивидуальность выплаты также не является, по мнению В. Бобкова, обязательной: почему бы, например, выплату представителю домохозяйства (семьи), доводящую её душевой доход до базового уровня, не рассматривать как форму ББД?

Переход от адресных к универсальным безусловным базовым выплатам является, по мнению В. Бобкова, объективным и вытекает из принципа распределения благ пропорционально базовым (основным) потребностям людей. Многочисленные эксперименты по введению ББД свидетельствуют о том, что в современных обществах осознана необходимость в таком универсальном социальном трансферте.

В докладе В. Бобкова была обоснована целесообразность переходных форм введения ББД, обусловленных ментальными, финансовыми, политическими и др. ограничениями. Это означает, что в современных обществах выплата базового дохода, как правило, оговаривается рядом условий: выплаты осуществляются целевым категориям граждан (т.е. не являются универсальными) в небольшом размере (как правило, соизмеримом с национальным прожиточным минимумом) и в ограниченные сроки.

При кажущейся простоте этого инструмента экономической и социальной политики в ряду

${ }^{3}$ Официальный сайт РЭУ им. Г.В. Плеханова. URL: https:// www.rea.ru/ru/org/managements/Nauchnyjj-centr-ehkonomikitruda/Pages/news.aspx (Дата обращения: 01.07.2021). 
многочисленных других последствия его введения могут сказаться на кардинальных вопросах преобразования институтов государства, общества и жизни его граждан, таких как: политические цели и достижение общественного консенсуса; трансформация сферы труда и занятости; изменение соотношения рабочего и свободного времени; распределение уровня и качества жизни и др.

В аспекте политических целей и достижении общественного консенсуса по их реализации докладчиком был поставлен вопрос: «Является ли введение ББД новым инструментом трансформации капитализма или это проявление разворота к преодолению отчуждения граждан от национального богатства, независимо от того, осознается ли это в политическом и в общественном сознании или нет?». Если руководствоваться гипотезой о введении ББД для приспособления капиталистической системы к увеличивающимся сложностям извлечения возрастающей прибыли, и анализировать в этом аспекте действия власти и крупного бизнеса, то, по мнению В. Бобкова, можно усмотреть в этой концепции т.н. «оптимизацию» капитализма, «откуп» от работника выплатой ему ББД под словесным прикрытием стремления к социальной справедливости. Если же руководствоваться гипотезой о возрастании роли государства как социального государства, как «поставщика смыслов существования» и создания условия для их воплощения при поддержке коллективных усилий по созданию и справедливому распределению общественных благ, то, как отметил докладчик, можно усмотреть за введением ББД концепцию преодоления отчуждения людей от национального богатства, движения в направлении социальной справедливости, в направлении новой модели социализма [3].

Ответ на этот вопрос В. Бобков связал с политическими, экономическими и другими условиями в конкретных странах, определяющих целеполагание своего развития и принимающих или не принимающих концепцию ББД. В России капитал проходит стадию первоначального накопления при поддержке государственных институтов, направленность деятельности которых он лоббирует в своих интересах. Поэтому власть и бизнес не считают нужным применять концепцию ББД даже для «оптимизации капитализма». Их интересы, из-за слабости общественного контроля за властью и крупным бизнесом, реализуются в полной мере без необходимости введения переходных форм ББД. Это выражается в преобладающем негативном отношении к подобным выплатам; в использовании элементов концепции ББД, в основном, в конъюнктурных целях в период выборных компаний, в ограниченности применения этого инструмента в острой фазе COVID-19 и минимизации базовых выплат по мере выхода из неё.

Юрий Квашнин, руководитель Центра европейских исследований ИМЭМО РАН, в своём докладе констатировал, что интерес к концепции ББД со стороны общества и политических элит, как правило, усиливается во времена слома прежних парадигм развития или масштабных социальных потрясений. В последнее десятилетие произошло и то, и другое. Накопилась усталость от неолиберального подхода к социальной и экономической политике. Такие вызовы, как социальное расслоение, прекаризация населения, в перспективе технологическая безработица - требуют новых решений. На фоне начавшегося в 2020 г. пандемического кризиса появились новые доводы в пользу базового дохода (БД) - возможность помочь всем гражданам, пострадавшим от пандемии, и простота реализации схемы в условиях локдаунов.

По мнению Ю. Квашнина, в политической плоскости главным результатом 2020 г., помимо активизации дискуссий о БД в целом и включения его требования в программы ряда партий, стало смещение акцента в сторону анализа потенциала его использования в качестве временной меры. Были идентифицированы основные преимущества экстренного БД по сравнению с другими формами раздачи т.н. «вертолётных денег». Среди них главные - его универсальный характер, позволяющий оказать помощь гражданам, исключённым из систем социальной защиты, и простая процедура выплат. Вместе с тем аргументы «против» перевесили. Главной причиной отказа от экстренного БД стали опасения политических элит западных стран (в меньшей степени - развитых стран Восточной Азии) относительно того, что регулярные денежные перечисления могут быть восприняты населением как норма, а отказ от них - как нарушение нового социального контракта.

В докладе Ю. Квашнина были обозначены ряд вьззовов, с которьми в будущем может бьть связана имплементаиия кониепиии БД.

1. В обществе пока не сформировался отчётливо выраженный запрос на переход к БД. Хотя опросы общественного мнения, казалось бы, свидетельствуют о том, что весомая, а в некоторых странах подавляющая часть населения эту идею поддерживает, понимание того, как именно БД будет работать, остаётся на низком уровне. Во многом тематика БД остаётся мифологизированной; распространено убеждение, что данная схема приведёт к иждивенчеству, отрицательно повлияет на занятость (хотя пилотные программы это не подтверждают).

2. Серьёзной проблемой является использование концепции в популистских целях оппозици- 
онными политиками. Плохо проработанная, изобилующая ошибками и неточностями программа Эндрю Яна (участника праймериз Демократической партии США), выдвижение программы БД партией «Ниппон Исин но кай», заигрывание с идеей представителями Шотландской национальной партии - вот далеко не полный перечень таких примеров.

3. Для политических элит введение БД сопряжено с неприемлемыми рисками. Его экономические последствия с трудом поддаются математическому моделированию, а имплементация БД в Монголии - единственный эксперимент в масштабах всей страны - закончилась неудачей. Кроме того, отказ от традиционных форм социальной помощи в пользу прямых и равных денежных выплат для находящихся у власти политиков может оказаться элементарно невыгодным. Очевидно, что БД - это значительно более прозрачная и менее коррупциоёмкая форма социальной защиты, нежели те, что сложились в большинстве стран. В особенности это относится к развивающимся странам с распространёнными практиками клиентелизма, где государство использует социальные выплаты в своих политических целях.

4. Ряд инициатив, связанных с БД, в том числе пилотных программ, показал противоречивые результаты, что было связано с их некорректной реализацией. Так, при осуществлении эксперимента в Финляндии был нарушен фундаментальный принцип безусловности денежных выплат, поскольку деньги получали только безработные граждане. Отсюда, по мнению Ю. Квашнина, возникает закономерный вопрос - не получится ли, что такие эксперименты приведут не к популяризации идеи, а, напротив, к её дискредитации?

В докладе Александра Золотова, заведующего кафедрой экономической теории и методологии ННГУ им. Н.И. Лобачевского, акцент был сделан на проблемах обретения «голоса» БД в России. Как отметил спикер, работники России, особенно из числа низкооплачиваемых, нуждаются в усилении социальной поддержки со стороны государства. Это вовсе не свидетельство социального иждивенчества. Как показывают данные социологических исследований [13], те категории работников, которые высказываются за усиление социальной поддержки, работают в среднем по 11 часов в день. К сожалению, общий заработок за это продолжительное рабочее время оказывается меньше среднего по региону. Другими словами, низкооплачиваемые работники, по сути, исчерпали возможности самостоятельно добиться приемлемого уровня жизни для себя и своих семей. По мнению А. Золотова, это делает целесообразным использование ББД или, по крайней мере, его переходных форм.
В научной литературе справедливо отмечается, что реализация такой масштабной социальной меры требует коллективного представительства наличие «голоса» [24]. Профсоюзы - потенциально самая доступная для работников организация, способная стать голосом за введение ББД. В России около 21 млн членов профсоюзов, что составляет $28 \%$ от экономически активного населения.

Ситуация обретения работниками «голоса» в поддержку ББД, по мнению А. Золотова, осложняется тем, что ФНПР, охватывающая большинство членов профсоюзов, пассивна в отстаивании интересов работников. Как отметил А. Золотов, в её нынешнем виде она не в состоянии быть голосом продвижения ББД.

Имеется также Конфедерация труда России относительно малочисленная, но включающая самые активные профсоюзы (авиадиспетчеров, «Действие» и т.д.), которая, по мнению А. Золотова, может быть голосом в пользу ББД. Вместе с тем, и в её рамках, как отметил докладчик, проявляется особенность профессиональных союзов приоритет локальных интересов.

Для поддержки ББД, как полагает А. Золотов, требуется институт, способный отстаивать общие интересы более широкого круга граждан политическая партия. Однако партии, поддерживающие требование ББД, как отметил А. Золотов, не доминируют в Государственной Думе РФ и не опираются на профсоюзы. Налицо, «порочный круг»: партии связывают продвижение ББД с парламентской деятельностью, оставляя Конфедерацию труда России вне активной борьбы за ББД. В то же время без активной массовой поддержки проекта ББД со стороны профсоюзов такие партии не в состоянии продвинуть этот проект в Государственной Думе.

Отмеченная проблема, как считает А. Золотов, в принципе, решаемая. С одной стороны, кто-то из известных политических лидеров должен выйти из «колеи» и обратиться к профсоюзам за поддержкой ББД. С другой, кто-то из ярких профсоюзных лидеров должен выйти из «колеи» и возглавить, по сути, политическое движение в поддержку ББД. И то, и другое объективно возможно.

Профессор Бернхард Ноймэркер ${ }^{4}$, професcop кафедры экономической политики и теории конституционной экономики им. Гётца Вернера,

4 Б. Ноймэркер является также автором модели чистого базового дохода (Net Basic Income), в которой описывается способ эффективного внедрения одной из переходных форм ББД в качестве антикризисной меры поддержки общества, которая впоследствии трансформируется в полную форму УБД, также доказывается более низкая стоимость реализации такой модели по сравнению с используемыми мерами поддержки. Данная модель была представлена профессором в Бундестаге на заседании, и, несмотря на то, что была отклонена, дорабатывается и готовится к полноценной публикации. 
Университет Фрайбурга, основатель и директор Фрайбургского Института исследований базового дохода FRIBIS (Германия), в своём докладе определил стратегию внедрения ББД через переходные формы, а также раскрыл тему ББД как средства борьбы с неравенством.

Б. Ноймэркер начал своё выступление с того, что в определениях ББД «безусловность» означает отсутствие необходимости доказывать нуждаемость для получения, а «универсальность» - возможность получения выплаты каждым членом общества, вне зависимости от наличия работы, типа работы и прочего. Таким образом, необходимо разделять безусловный базовый доход (ББД) и универсальный базовый доход (УБД), и ББД является эффективной и крайне важной переходной формой к УБД.

В настоящее время в Германии работают две системы социальной поддержки трудящихся система стимулирования занятости «Пособия по безработице II», известная как «Хартц $4 »^{5}$ (status quo), нацеленная на обеспечение участия индивидов на рынке труда в частном секторе, и берлинский «Солидарный гражданский доход» [15], подразумевающий получение выплат безработными взамен на общественно полезные работы или занятость в определённых государственных учреждениях. Б. Ноймэркер отмечает, что в последней программе «солидарность» определена иначе, нежели в концепции ББД, потому что она начинается в момент участия в жизни общества, в то время как «солидарность» ББД не подразумевает требования к участию в чём-либо в принципе, тем более, «взамен». Обе системы основаны на идее интенсивного мотивирования к труду, к получению оплачиваемой работы, в частном или общественном секторе. Во время поиска индивид получает некоторое пособие в зависимости от степени нуждаемости, то есть финансовую поддержку. Однако, по мнению Б. Ноймэркера, такие системы на самом деле не способствуют увеличению мотивации, а лишь являются принуждающими к труду и к участию в частном секторе экономики.

Анализируя далее концепцию с точки зрения теории конституционной экономики, Б. Ноймэркер начинает с того, что индивиды могут получить потребительский суверенитет и свободу в неолиберальном или социо-либеральном смысле в виде собственности, но для получения соответствующей заработной платы надо усердно работать. Реализация потребительского суверенитета, в свою очередь, возможна только для потребительских

${ }^{5}$ Hartz IV. URL: https://www.arbeitsagentur.de/lexikon/ hartz-4 (Accessed: 24.08.2021); https://www.hartziv.org/ (Assessed: 24.08.2021). товаров, которые покупаются на некотором рынке, для формирования которого требуется рост ВВП, что является, в конечном счёте, внешним фактором влияния на силу суверенитета. При этом действовать индивидам приходится в системе с элементами принуждения к труду, а также в государствах, ориентированных на максимизацию ВВП. И в таком случае в контексте борьбы с неравенством возникает вопрос: если речь идёт о максимизации ВВП, а это подразумевает, что ВВП рассматривается с утилитаристкой точки зрения, то существует ли некий общественный контракт, который подтверждает согласие общества функционировать именно по утилитаристским принципам? Б. Ноймэркер подчеркивает, что ВВП практически в любой стране считается внешним принципом справедливости. При этом ещё со времён Джона Роулза теория справедливости подчёркивает, что принцип справедливости может лежать в основе общественного устройства лишь в том случае, когда общество само соглашается на правила определения этой справедливости, в явном или неявном виде. И Роулз говорил [23], что справедливость отвечает принципу максимина разницы, то есть, усиление позиции слабейшего, а не суммированию всех позиций, потому что прямое суммирование (как, например, при подсчёте ВВП) ведёт к росту неравенства, в то время как принцип максимина как раз позволяет значительно снизить неравенство. И если утилитаристская теория считает, что работа с социальной целевой функцией ведёт к росту эффективности, притом, что неизменными остаются устойчивость и справедливость, Роулз же, наоборот, переворачивает эту идею и говорит о том, что в целевую социальную функцию как раз необходимо включать справедливость и частично устойчивость, в то время как эффективность в отношении потенциальной компенсации как раз должна быть ограничением, и это и было бы изменением парадигмы. И именно такой сдвиг критически необходим для перехода от систем стимулирования занятости к системе, основанной на универсальном безусловном базовом доходе.

ББД отличается от, например, Солидарного дохода справедливостью в отношении участия в рабочих отношениях, а главное - созданием ценности свободного от работы времени, заключает Б. Ноймэркер. Важным аспектом в системах нового типа должно стать меняющиеся понятия работы, а именно, строгое разграничение понятий неоплачиваемой работы и свободного времени и способствование продуктивному и креативному проведению этого свободного времени. И тогда получится, что потребительский суверенитет в плане получения пресловутой свободы в неоклас- 
сическом трансформируется в суверенитет времени, позволяющий использовать эту свободу, распоряжаться своим временем для самоопределения в иных формах, нежели через потребление. И концепция ББД как раз подразумевает новую парадигму, в которой придётся уйти от необходимости доказывать нуждаемость и соответствие установленным критериям, и прийти к описанному выше суверенитету времени, что позволит обществу реализовать новые «правила» справедливости.

Переходя к теме политической релевантности ББД, Б. Ноймэркер отметил, что в Германии сегодня наблюдается следующий феномен: концепция ББД пока недостаточно поддерживается, однако большое количество политических программ и предложений в итоге основаны на переходных формах ББД. Например, недавно в парламенте появилась идея «базовой пенсии» [22], заключающаяся в том, что все, кто работал более 35 лет и платил налоги, должны безусловно получать 1050 евро в месяц. В данном случае критерий соответствия описывается фискальными требованиями, то есть, фактом уплаты пенсионных отчислений, потому что от этих налоговых поступлений зависит напрямую финансирование базовой пенсии. Но особенность модели заключается в том, что другой, возможно, даже большей частью финансирования должны стать новые налоги, например, экологические, которые будут введены позже.

Б. Ноймэркер привёл ещё пример универсальных систем выплат: социал-демократы предлагают ввести так называемый «климатический бонус» [16] - каждый гражданин получит выплату из пула, сформированного за счёт углеродного или других экологических налогов. И тут присутствует новаторский подход: индивид получает так называемую «остаточную выплату», которая зависит от загрязнения воздуха $\mathrm{CO} 2$, а именно - чем выше загрязнение воздуха, тем больше компенсация. Такая мера нацелена на снижение неравенства, вызванного экстерналиями, создаваемыми загрязнителями экологии, и реализуется принцип справедливости: если участник общества не является источником загрязнения окружающей среды, то он получает выплату, в противном случае - платит налог.

Консервативный Институт экономических исследований им. Лейбница в Мюнхене предлагает ввести «гражданский фонд» [17] - дополнительную пенсию, которая должна быть основана на отдаче от общественного капитала: государство инвестирует в рынок капитала, а полученные от этих инвестиций средства должны направляться в этот фонд. И тогда индивидам можно будет выдавать выплаты в размере тех же 1050 евро в месяц для всех пенсионеров. Опять же, такая выплата безусловная, но не универсальная. Однако Б. Ноймэркер отметил, что если объединить такую систему с какой-либо из имеющихся, где уже реализован элемент безусловности, например, с системой пособий на ребенка, которые получают все родители в Германии, то уже получилась бы модель социальной поддержки, в которой уже две категории граждан получают безусловный (хоть и не универсальный) базовый доход. Но определённые трудности на сегодняшний момент связаны с тем, что всех остальных участников общества государство пока не готово поддерживать такими мерами, как УБД. Тем не менее, в период пандемии государство выплачивало на безусловной основе поддерживающее пособие получателям выплат по «Хартц 4».

Переход к УБД является реалистичным, нужно только пользоваться правильно определёнными переходными формами, резюмирует Б. Ноймэркер. Швейцарский сценарий был реализован ультимативно, что свойственно для систем прямой демократии, но для парламентской демократии, равно как и для авторитарных государств, подходят сценарии постепенного перехода. Кроме того, есть проблема с пилотными экспериментами: во-первых, не выполняется критерий универсальности, а во-вторых, эксперименты могут показать только некоторые краткосрочные эффекты, причём не всегда положительные, в то время как ББД - это долгосрочная перспектива и изменение парадигмы.

Но даже сегодня, исходя из имеющихся инициатив, уже можно обеспечить постепенный переход к УБД с разных сторон. Введение углеродного налога, климатического бонуса - это участие со стороны общественного сектора, базовая пенсия - со стороны, скорее, частного сектора, пилотные эксперименты поддерживают всё это. И сегодня ввиду кризиса, связанного с пандемией коронавируса, ББД может служить основой для мер по выходу из этого кризиса, подвёл итог Б. Ноймэркер.

Энно Шмидт, научный сотрудник кафедры Экономической политики и теории конституционной экономики им. Гётца Вернера Университета Фрайбурга и Фрайбургского Института исследований базового дохода (Германия), посвятил доклад своему опыту организации в виде референдума первой общенародной дискуссии о введении ББД в Швейи,арии. Э. Шмидт напомнил, что в июне 2016 г. граждане Швейцарии голосовали за внедрение универсального БД на территории Швейцарии. Текст народного инициативного предложения, вынесенный впоследствии 
на референдум, ${ }^{6}$ был подписан 126 тысячами граждан в течение 18 месяцев. Результатом референдума явилась поддержка данной инициативы 23,1 \% голосовавших, в то время как подавляющее большинство принимавших участие в голосовании высказалось против. После провала на референдуме концепция БД долгое время не обсуждалась в Швейцарии вообще. Однако в настоящее время дискуссии о БД возобновляются, и готовится новое инициативное предложение относительно ББД с учётом предыдущего полученного опыта.

Текст инициативного предложения, признаёт Э. Шмидт, был достаточно свободным и размытым. В предложение также намеренно не включалось конкретное значение размера БД, поскольку предполагалось, что как только будет обозначена конкретная сумма, вся дискуссия сведётся к обсуждению именно этой цифры. По мнению организаторов референдума, дискуссия о такой сложной для принятия концепции как ББД должна держать в фокусе содержательную часть идеи о базовом доходе, а не расчёты. В тексте также не упоминалось финансирование БД: во-первых, потому что это было бы нарушением правил референдума о количестве вынесенных вопросов на одну и ту же тему; во-вторых, это перетянуло бы внимание с части о важности универсальности и безусловности. Тем не менее, в медиа попала информация о конкретной сумме БД, и, как и опасались организаторы, весь фокус действительно ушёл на её обсуждение, что привело к большому количеству недопонимания, как и упоминание особого типа финансирования.

Э. Шмидт обратил внимание на важный опыт, полученный организаторами референдума, который он сформулировал в следующих четырёх положениях.

1. Как только в контексте обсуждения БД появляется конкретное значение размера выплат по базовому доходу, медиа и общество моментально переключают внимание на эту конкретику. Причиной тому является внутреннее доверие к числам и расчётам, объясняет Э. Шмидт, что даёт ощущение большей уверенности относительно собственной будущей позиции в условиях неопределённости. Учитывая, что идея БД, в особенности в части универсальности и безусловности, сама по себе достаточно сложная для осознания и новая: обществу требуется некоторое количество итераций для понимания всей глубины концепции. Необходимо «прожить» эту идею, изменить мышление, уйти от старых психологических установок, в том числе связанных с устройством

${ }^{6}$ Eidgenössische Volksinitiative 'Für ein bedingungsloses Grundeinkommen. URL: https://www.bk.admin.ch/ch/d/pore/ vi/vis423t.html (Accessed: 16.08.2021). общества в недалёком прошлом, в особенности, что касается понятия «работа» и некоторых ролей государства. Это и есть новаторство и ценность данной концепции: БД - это не про деньги, а про абсолютную безусловность.

2. Как только появляется упоминание конкретного вида финансирования БД, любые участники дискуссий тут же переключаются на это и сразу резко критикуют всю концепцию целиком, выступая против любой предложенной схемы финансирования.

3. Вследствие первых двух пунктов, люди демонстрируют тенденцию к перескакиванию от важных и сложных идей к более простым, понятным пунктам. Опыт подтвердил склонность общества критиковать аспекты, которые, если и будут актуальными, то явно не в среднесрочном периоде. При этом общество тут же начинает игнорировать первые шаги к реализации БД, в том числе и переходные формы. Таким образом, делает вывод Э. Шмидт, для возникновения конструктивного обсуждения, например, вопросов финансирования или размера выплат, необходимо сначала сформировать общественное положительное мнение относительно самой концепции БД.

ББД, отметил Э. Шмидт, касается всех участников общества, и в итоге, прямо или косвенно, всё равно будет финансироваться коллективно: это и есть демократический суверенитет, являющийся результатом прозрачности системы и возможности наблюдения за денежными потоками. С внедрением ББД многие принципы изменятся, произойдут некоторые синергии и эффекты домино - в любом случае, точное прогнозирование на данном этапе не может являться целостным [19]. Существующие системы социальной поддержки направлены, в основном, исключительно на нуждающихся граждан, в то время как система социальной защиты, основанная на БД, не является направленной в принципе, потому что каждый член общества получает этот вид дохода. И, подчёркивает Э. Шмидт, в обществе с ББД не происходит фрагментации общества: отсутствует деление на сильных и слабых, успешных и провальных, бедных и богатых в неоклассическом понимании, ленивых и целеустремленных, хороших и плохих. В таком обществе уходит понятие категоризации, которое многим индивидам необходимо для того, чтобы через сравнение оценить своё собственное положение. И противникам, как правило, именно это и кажется невыносимым. Но именно ББД и является основой функционирования нового общества.

4. Невозможно фокусироваться на интересах отдельных социальных групп при дискуссии в обществе целиком. К примеру, можно найти ар- 
гументы, которые отвечают «левой» философии, или аргументы, которые близки, в частности, социалистам, можно апеллировать к учёным или неолибералам, целенаправленно. Однако если в дискуссии с участием представителей разных групп использовать, например, либеральные аргументы для обращения к соответствующим группам, то тут же теряются, например, сторонники других политических идей, и эти группы становятся уже оппонентами. Э. Шмидт отмечает, что на самом деле идея ББД является нейтральной, и аргументы за БД, как оказывается, находятся в любой политической идеологии. В конечном счёте становится ясно, что диалектика сводится к одному вопросу - описанию образа человеческой сущности.

Э. Шмидт обратил внимание на результаты организованного перед референдумом опроса, который показал, что в случае получения БД респонденты: занялись бы образованием (54\%), стали бы проводить больше времени с семьёй (53\%), занялись бы волонтёрством (40\%), стали бы покупать больше экологичных товаров (35\%), стали бы работать меньше (3-4 дня в неделю) и выделять время на другие дела (34\%), занялись бы предпринимательством (22\%), сменили бы место работы (13\%), возможно, перестали работать $(8 \%)$, точно перестали бы работать вообще (что бы ни подразумевалось под работой) (2\%). Таким образом, $90 \%$ респондентов, сделал вывод Э. Шмидт, вовсе не собираются покидать рынок труда вопреки распространённому мнению. При этом большинство опрошенных, которые выразили желание работать меньше, отметили, что хотят в высвобожденное время заниматься помощью близким, соседям, другим людям или любой социально важной активностью вне зависимости от того, будет она оплачена или нет.

В заключение Э. Шмидт добавил, что в 2016 г. явка на референдум составила 46,4\%, «за» проголосовало 23,1\%. Организаторы референдума считают это хорошим результатом для такой сложной задачи и первого крупного опыта и продолжают работать над следующим шагом.

Алексей Волков и Роман Сейткалиев (ИМЭМО РАН) сделали акцент на экспериментах с ББД, проанализировав опыт Финляндии и развивающихся стран.

Алексей Волков, к.э.н., заведующий Сектором экономики европейских стран ИМЭМО РАН, обратился к опьту Финляндии, первой европейской страны, где вопрос о ББД был поднят на общегосударственный уровень. Эксперимент по введению ББД был проведён в Финляндии в 2017-2018 гг. [20] и должен был выяснить, можно ли таким путём повысить занятость. В экспери- менте приняли участие 2000 безработных в возрасте от 25 до 58 лет, которые получали 560 евро в месяц, при этом выплата не прекращалась и после того, как они находили работу. Как отметил А. Волков, предварительные результаты эксперимента оказались практически полностью противоположными ожидаемым. Получатели БД заявляли, что не готовы хвататься за любую работу, и предъявляли всё больше требований. Они занимались поиском не намного активнее, чем другие безработные. Произошло некоторое повышение их уровня благосостояния, а также участники стали чувствовать себя более уверенными и физически здоровыми. Окончательные итоги были таковы: небольшой эффект для занятости, но хорошее психологическое воздействие. Финляндия была идеальной площадкой для экспериментов в области социального обеспечения. Но «бесплатные» деньги представляли собой фактически безусловное пособие по безработице, а эксперимент с БД не был направлен на сокращение числа бедных или борьбу с неравенством - главной его задачей являлось "содействие занятости» ${ }^{7}$ [8]. Такой подход, как отметил А. Волков, противоречит самой идее «универсальности» базового дохода.

Роман Сейткалиев, младший научный сотрудник ИМЭМО РАН, представил результать действующих и завершённых проектов БД в развиваюшихся странах в контексте экономи ческого поведения получателей выплат. Проанализировав опыт проектов ББД, спикер отметил, что безусловные денежные выплаты, действительно, положительно влияют на уровень и качество жизни реципиентов. Структура расходов домохозяйств выявила преимущественно ответственное финансовое поведение получателей. Тем самым было опровергнуто предположение о неспособности малограмотного бедного населения адекватно распорядиться прямыми денежными выплатами. ББД способствовал самоорганизации людей, установлению горизонтальных связей для решения общих вопросов наблюдаемой местности. Нередки стали совместные бизнес-проекты групп людей, объединяющих свои активы для приобретения средств производства. Запущенные в беднейших странах Африки и Азии проекты показали, что одинаковые переводы вне зависимости от пола получателя позволяют сгладить перекосы традиционного для этих мест патриархального общества и улучшить положение женщин всех возрастов. Девочки получили возможность ходить в школу, а женщины стали чаще принимать участие в планировании семейных

Халява кончилась: почему Финляндия отказалась от выплаты базового дохода // РИА Новости. 26.04.2018 (Дата обращения: 13.10.2021). 
расходов и смогли реализовать свои профессиональные амбиции. Несмотря на очевидные плюсы уже завершённых проектов, этот опыт так и не был распространён на общенациональный уровень. По мнению докладчика, главным препятствием стал вопрос финансирования проектов: и у благотворительных организаций, и у органов государственной власти оказалось недостаточно средств для масштабирования пилотных программ на всю страну; перед государствами стоит выбор - либо финансировать социальную сферу, либо вкладывать средства в национальную экономику, развитие инфраструктуры.

Иранский опыт, по мнению Р. Сейткалиева, свидетельствует о том, что данный проект правильнее рассматривать не столько как проект ББД, сколько как попытку проведения денежной реформы, нацеленной на переориентацию экономики с экспорта углеводородов на расширение внутреннего спроса. Проект ББД в Монголии (первая попытка имплементировать концепцию на национальном уровне) показал, что в этой стране безусловные денежные выплаты быстро привели к положительным изменениям в жизни населения, но негативно сказались на государственных финансах. В итоге вместо финансирования ББД предпочтение было отдано стимулированию экономического роста посредством реализации инфраструктурных проектов.

Елена Одинцова (ИСЭПН ФНИСЦ РАН, РЭУ им. Г.В. Плеханова) и Екатерина Черных (ИСЭПН ФНИСЦ РАН) в своих докладах представили результаты опроса экспертов, проведённого в 2020 г. в рамках научного проекта «Безусловный базовый доход как регулятор повышения уровня и качества жизни: теоретико-методологическое обоснование, переходные формы и инструментарий для тестирования в России».

В докладе Елены Одинцовой, к.э.н., ведущего научного сотрудника ИСЭПН ФНИСЦ РАН, ведущего научного сотрудника Научного центра экономики труда РЭУ им. Г.В. Плеханова, было показано российское пространство обсуждений по вопросу о иелесообразности введения ББД через призму полученных результатов опроса российских экспертов. Опрос экспертов был проведён в августе-октябре 2020 г. методом заочного анкетирования. В нём приняли участие 52 эксперта из г. Москвы и других российских регионов, представляющих четыре категории специалистов: 1) научно-исследовательское сообщество, 2) ведущие ВУЗы, 3) бизнес-сообщество и профсоюзы, 4) органы государственного и муниципального управления [5].

Опрос показал, что эксперты разделены по вопросу о готовности России к введению ББД:
$45,1 \%$ уверены, что Россия не готова ни к полному, ни к частичному (переходные формы) введению ББД, тогда как большая группа экспертов (почти $55 \%)$ высказались в пользу готовности - к переходным формам ББД (49\%) или к его полному инструментарию (около 6\%). Неготовность России к ББД, как отмечалось в докладе, аргументируется экспертами: необходимостью дополнительного изучения и осмысления, широкого общественного обсуждения по целому комплексу вопросов, связанных с реализацией ББД (механизм распределения, источники и пр.); необходимостью определиться с целью введения ББД - для решения каких проблем он будет применяться и возможно ли решить их с помощью ББД; неисчерпованностью возможностей существующих принципов осуществления социальных выплат, которые возможно развивать и совершенствовать; отсутствием необходимых финансовых средств; потенциальными негативными последствиями для сферы занятости и увеличением иждивенческих настроений; необходимостью времени для подготовки (подготовительный период для экономики, планирование бюджета и т.п.); а также другими аргументами [5].

По мнению экспертов, которые выступили за готовность России к введению ББД, это целесообразно, в первую очередь, для смягчения (преодоления) проблем бедности и социально-экономического неравенства, обеспечения минимального уровня жизни уязвимых категорий населения, обеспечения социальной справедливости (от более $50 \%$ до более $90 \%$ ответивших экспертов) $)^{8}$. Другие цели, в т.ч. связанные с регулированием рынка труда и сферы занятости, регулированием баланса рабочего и свободного времени, констатировал докладчик, получили заметно меньшую поддержку среди экспертов [5].

Е. Одинцовой также были представлены полученные экспертные оценки относительно практических вопросов реализации инструментария ББД в России. Его имплементация может быть осуществлена, прежде всего, в форме гарантированного минимального дохода ${ }^{9}$ (ГМД), в пользу которого высказались более $70 \%$ ответивших экспертов. В части возможных источников финансирования ББД в России в рамках исследования среди экспертов не было выявлено общей позиции: ими отмечались реорганизация системы социальной поддержки и экономия от сокращения администрирующего адресную социальную поддержку

\footnotetext{
8 У экспертов была возможность выбрать несколько вариантов ответа.

9 Предполагает доведение адресной поддержкой душевого дохода в домохозяйстве до установленного порогового уровня, например, регионального душевого прожиточного минимума.
} 
аппарата, налоги, рента и специально созданные фонды. Также не было выявлено общей точки зрения по вопросу о способе реализации ББД: по мнению экспертов, он может дополнить существующие меры поддержки, заменить существующие меры (механизмы) социальной поддержки или может быть государственной гарантированной выплатой каждому гражданину страны от рождения до смерти [5].

Вместе с тем, как отмечалось в докладе, эксперты высказались в пользу целесообразности реализации в России пилотных проектов по введению ББД: их поддержали более 80 \% ответивших экспертов. Целевой категорией для пилотной апробации инструментария ББД, по экспертным оценкам, должны стать, прежде всего, малоимущие семьи с детьми (их выделили $80 \%$ ответивших экспертов). Целевая группа, по мнению 54,2\% ответивших экспертов, должна быть сформирована по нескольким репрезентативным субъектам, а продолжительность пилотной реализации ББД должна быть не менее 2-3 лет [5].

В докладе также были высвечены обозначенные экспертами потенциальные позитивные эффекты при введении ББД, а также возможные риски. Введение ББД, по мнению экспертов, прежде всего, сопряжено с такими рисками, как необходимость больших дополнительных расходов государственного бюджета, что может привести к росту бюджетного дефицита или государственного долга (74\% от числа ответивших экспертов), а также рост иждивенчества, снижение мотивов и стимулов к труду, падение производительности труда $(60 \%)^{10}$. Наиболее значимые потенциальные позитивные эффекты введения ББД, как отметил докладчик, эксперты связывают с возможностью снизить уровень и глубину бедности (более $80 \%$ ответивших экспертов) и социально-экономическое неравенство (более $50 \%)^{11}$ [5].

Екатерина Черных, к.э.н., старший научный сотрудник ИСЭПН ФНИСЦ РАН, продолжила представление полученных результатов экспертного опроса, сосредоточив внимание на основных направлениях влияния ББД на сберу занятости населения.

Среди экспертов, как отметила Е. Черных, apгументировались разные точки зрения относительно возможных направлений влияния ББД на сферу занятости. Так, часть экспертов полагают, что введение ББД может привести к снижению занятости и/или мотивов и стимулов к ней. Они обращали внимание на риски, связанные с увели-

\footnotetext{
10 У экспертов была возможность выбрать несколько вариантов ответа.

11 У экспертов была возможность выбрать несколько вариантов ответа.
}

чением неполной занятости, сохранением вакантными низкооплачиваемых рабочих мест, стимулирования работодателей к выплате более низкой заработной платы и пр. Другая группа экспертов считают, что влияние ББД будет, напротив, положительным, связывая его с увеличением занятости, расширением возможностей для неё и пр. Среди экспертов также существует точка зрения, что на занятости и стимулах к ней введение ББД практически не отразится.

Экспертами также высказывалась точка зрения, что ББД может привести к тому, что люди станут больше вовлечены в неоплачиваемую работу: например, волонтёрская деятельность, работа в домашнем или приусадебном хозяйстве. Некоторыми из экспертов были отмечены потенциальные риски роста неоплачиваемой («принудительной») работы. Влияние ББД на соотношение баланса рабочего и свободного времени, по мнению экспертов, может быть разнонаправленным. Одни эксперты ожидают увеличения свободного времени, которое будет направляться на обучение, повышение квалификации, изменения качества досуга, структуры досуговой деятельности, другие полагают, что ББД не окажет существенного влияния на перераспределение рабочего и свободного времени и качество досуга или его влияние будет отрицательным.

Как отмечалось в докладе, потенциальное влияние введения ББД на «теневую» занятость, по мнению экспертов, может быть разнонаправленным: 1) может привести к росту «теневой» занятости (если размер трудового дохода будет учитываться при определении права на ББД, это может стимулировать претендующих на ББД скрывать реальный размер такого дохода; при росте налоговой нагрузки на работающих в связи с ростом расходов госбюджета при введении ББД); 2) может привести к снижению «теневой» занятости (в отношении той её части, где она являлась вынужденной для работников или служила дополнительным источником доходов).

В докладе также показано, что согласно полученным экспертным оценкам, ББД может способствовать росту неформальной занятости (при смещении в предпочтении работодателей при сотрудничестве с работниками с бессрочного трудового договора и полного рабочего дня в сторону проектной работы). Также экспертами высказывалась точка зрения, что влияние ББД будет определяться самим критериальным инструментарием (размером ББД, категориями получателей, степенью безусловности БД и др.).

Александра Пилюс, аспирант кафедры экономической политики и теории конституционной экономики им. Гётца Вернера, Университет 
Фрайбурга, научный сотрудник Фрайбургского Института исследований базового дохода (Германия), посвятила доклад концепции ББД как основе системы социальной защиты в условиях развития новых форм занятости.

Существующие системы социальной защиты стремительно устаревают, потому что реализуются, в основном, по принципу «заплаток», а процессы, протекающие в общественной жизни, в экономике, на рынке труда, происходят очень быстро [24]. Например, цифровизация является неотъемлемой частью сегодняшней парадигмы развития, и имеются различные прогнозы относительно того, насколько серьёзные последствия ожидают мир ввиду цифровизации и автоматизации. Однако особенностью сегодняшней «революции 4.0» является, безусловно, экспоненциально растущая скорость развития и внедрения технологий, которые, в свою очередь, вносят глобальные изменения в сферу занятости. И системы социальной защиты уже не справляются со своими задачами, а государству приходится выделять средства на новые «заплатки». Таким образом, в современном обществе, по мнению А. Пилюс, наиболее актуальным вопросом является внедрение новых принципов устройства социальной поддержки общества для обеспечения долгосрочной устойчивости и адаптивности этой системы к новым вызовам.

ББД является одной из самых широко обсуждаемых концепций системы социальной защиты нового типа. Важной особенностью дискуссии о БД, как заметила А. Пилюс, является тот факт, что такая дискуссия неизменно происходит на междисциплинарном уровне и затрагивает большое количество самых разных аспектов жизни как каждого индивида, так и общества в целом. Эпидемия коронавируса подстегнула некоторые назревавшие на рынке труда изменения. Так, необходимость работать удалённо показала, что это вполне рабочий вариант организации трудовой деятельности. Это также позволило измениться в положительную сторону и отношению в обществе к тем, кто и до этого работал удалённо (например, к фрилансерам). Кроме того, наиболее востребованные специалисты, например разработчики или аналитики, представляют собой как раз ту категорию занятых, которой такая форма занятости наибольшим образом подходит.

Однако новым формам занятости сопутствуют также и проблемы, требующие решения и регулирования. Так, например, угроза прекаризации труда новых форм занятых - одна из таких проблем [25]. Кроме того, аспекты, связанные с распределением времени (в том числе, отсутствие суверенитета времени (см. доклад Б. Ноймэркера) - тоже актуальная проблема: нередко у человека, работающего удалённо, ненормированный рабочий день, а «правильное» отношение к труду таких занятых ещё не сформировалось нужным образом. Более того, пока что не существует рабочих механизмов самостоятельного определения того количества времени, которое работник в принципе готов эффективно уделять работе, а ведь далеко не все комфортно себя чувствуют, например, при классической 40-часовой рабочей неделе. Под комфортом подразумевается не только моральный комфорт, но и, что крайне важно, аспекты, связанные со здоровьем, следовательно, с трудоспособностью и эффективностью в долгосрочном периоде. Мотивация для работы в странах с высоким уровнем бедности, в том числе, пограничной, связана зачастую с необходимостью выживания - обеспечения базовых потребностей для себя и своей семьи. Кроме того, существующее, например, в российском обществе понятие «престижности» работы или профессий приводит к неоднозначному распределению занятых, созданию избытка трудовых ресурсов в одних сферах и нехватки ресурсов в других сферах, вероятно, более общественно полезных. Также зачастую люди не хотят получать квалификацию, потому что это либо по разным причинам не требуется, либо в этом нет экономического смысла, либо занимает несоразмерно много времени, в которое индивид должен параллельно самостоятельно обеспечивать себе прожиточный доход, в то время как система социальной защиты не предусматривает поддержку в таких ситуациях, особенно если гражданин не попадает в число нуждающихся.

Существуют также и проблемы, которые давно известны, но до сих пор не решены и даже не решаются. Так, например, женщины, которые занимаются домашним хозяйством и воспитанием детей, часто становятся полностью зависимыми от мужчин [28]. И тут, конечно, затрагивается и несколько архаичная система ценностей, и пресловутое отношение к работе как к вынужденной мере для выживания. Также не оплачивается работа по уходу и забота о других - а на это нужно то самое время, которое отнимает основная работа. В семьях, где оба родителя работают, дети воспитываются в меньшей степени самими родителями, более того, такие семьи нередко предпочитают ограничиться одним-двумя детьми, если не их отсутствием, вследствие чего возникает демографический перекос. Крайне нуждающиеся же семьи, наоборот, зачастую имеют троих детей и более, при этом не имея по факту возможности выбраться из ловушек бедности, что приводит к ещё большим затратам государства на вышеупомянутые «заплатки». 
Система социальной защиты, основанная на принципе обеспечения ББД, подчеркнула А. Пилюс, решает большинство подобных проблем. Кроме того, преимуществом такой модели для государства является хорошо прогнозируемая, если не фиксированная стоимость, поскольку идеальная модель предполагает минимум иных мер социальной поддержки. Сегодня существует множество схем БД, которые исследуются, просчитываются, обсуждаются, критикуются и поддерживаются. Это разворачивает множество важных дискуссий о том, какие способы социальной поддержки при такой модели более не требуются, как можно высвободить средства на финансирования БД, какие эффекты на разных уровнях можно наблюдать, как именно и как долго может проходить переход на такую модель, прежде чем положительные эффекты закрепятся, а ценности и отношения поменяются. Однако самыми важными предпосылками к переходу на принципиально новые социальные модели являются новые возможности и принципы организации труда, изменяющееся отношение к работе, к труду как таковому [26].

Важным условием успешного перехода на модели социальной защиты, основанные на БД, по мнению А. Пилюс, является необходимость перехода, по возможности, без тестового режима. Все преимущества БД, возможно, не раскроются в краткосрочном периоде, однако вышеупомянутое изменение ценностей и парадигмы занимает время [27]. Но обеспечить хотя бы базовый прожиточный минимум для любого гражданина России как право, как базис для всех последующих реформ она считает вполне выполнимой задачей.

Концепция ББД, делает вывод А. Пилюс, является оптимальной основой для системы социальной защиты нового типа в современном мире. Именно такая система может стать основой для того, чтобы использовать ресурс времени во благо граждан и защитить каждого от шоков и неизвестности будущих периодов.

В докладе д.э.н. Игоря Колмакова и к.э.н. Валентины Павловой, ведущего научного сотрудника Научной школы «Теории и технологии менеджмента» РЭУ им. Г.В. Плеханова, были представлены результаты исследования гипотетических возможностей и последствий для экономики от передачи условного базового дохода (УБД) безработным России. В качестве источников финансирования для проведения программы выплат УБД для безработных докладчиками рассматривались три варианта экономических процессов: создание Фонда УБД за счёт повышения доли фонда оплаты труда (ФОТ) в ВВП; изменение структуры налога на доходы физических лиц (НДФЛ); сумма первоначальных затрат на программу УБД берётся из Фонда национального благосостояния (ФНБ). При любом источнике финансирования произойдёт запуск макроэкономической спирали повышения ВВП (и консолидированного бюджета) за счёт повышения потребительского спроса. Далее «волна» ежегодных приростов консолидированного бюджета будет компенсировать необходимые ежегодные затраты. При этом все пропорции уже утверждённого (и при необходимости корректируемого) бюджета (на 2022-2024 гг.) остаются неизменными [6]. Авторами был проведён модельный эксперимент по выплатам безработным повышенных пособий в рамках программы УБД (что повышает конечное потребление домашних хозяйств). Прогноз развития экономики России с учётом реализации программы «УБД» был выполнен с использованием экономико-математической модели темпо-дефляторного типа, на которой рассчитывались последствия принятия решений на длительный (до 10 лет) период. Численный эксперимент проводился с использованием имитационно-экспертной модели воспроизводства ВВП экономики России Р1-4-0(2020-1) [2]. Все экономические характеристики модели соответствуют отчётности Росстата $^{12}$. В результате численного эксперимента авторами было выявлено существенное повышение темпов роста ВВП России и доходов консолидированного бюджета.

\section{О развитии научных исследований и реализации концепции ББД (дискуссионный ракурс)}

Дискуссия на международной научной конференции «Безусловный базовый доход как регулятор повышения уровня и качества жизни граждан и устойчивости общества: проблемы и возможные пути их решения» высветила основные направления широкого обсуждения и исследования проблематики ББД в России и Германии, а также в других странах ${ }^{13}[9 ; 11 ; 24 ; 27 ;$ и др.].

В условиях отсутствия общенациональных практик имплементации ББД при его полных критериальных основаниях дискуссии сторонников и противников ББД подпитывает нерешённость вопроса о последствиях (позитивных или негативных) при его введении для общества и государства, сферы труда и занятости, уровня и качества жизни и др. Исследование потенциальных последствий введения ББД продолжается в рамках пилотной апробации данного инструментария и имитационного моделирования [18; 21 ; и др.].

\footnotetext{
12 Национальные счета России в 2011-2018 годах: Стат. сб./ Росстат. М., 2018. 263 с.

${ }^{13}$ См., например: Basic Income Studies. URL: https://www. degruyter.com/journal/key/bis/16/1/html (Accessed: 24.08.2021)
} 
Введение и применение института ББД возможно лишь при высокой степени общественного согласия как часть нового общественного договора власти и общества. Необходим общественный консенсус по вопросам об экономическом положении страны, о причинах бедности и богатства, о допустимых границах социально-экономического неравенства, о перспективах соотношения рабочего и свободного времени, о доверии к власти и других ценностных представлениях о жизни в современных государствах [3].

В России в последние годы значительно активизировались исследования и проведение локальных экспериментов по введению переходных форм ББД. Из наиболее заметных исследований следует выделить два научных проекта, осуществляемых при поддержке грантов Российского фонда фундаментальных исследований. Проект «Безусловный базовый доход как регулятор повышения уровня и качества жизни: теоретико-методологическое обоснование, переходные формы и инструментарий для тестирования в России» (рук. Бобков В.Н., РЭУ им. Г.В. Плеханова) в практическом плане направлен на разработку моделей введения переходных форм ББД для ряда уязвимых категорий населения: малоимущих семей с детьми для преодоления абсолютной монетарной бедности, выпускников средних профессиональных учебных заведений, впервые выходящих на рынок труда, для поддержки их в период поиска первого стабильного места занятости, для работников с большой концентрацией признаков неустойчивой занятости. Проект «Концепция безусловного основного дохода и перспективы её реализации в условиях новых социальных и технологических вызовов» (рук. - Квашнин Ю.Д., ИМЭМО РАН) в практическом плане направлен на обобщение опыта введения ББД за рубежом.

Консенсус о необходимости введения ББД в экспертной среде ещё не достигнут. Это подтверждается и результатами опроса российских экспертов, проведённого в рамках научного проекта «Безусловный базовый доход как регулятор повышения уровня и качества жизни: теоретико-методологическое обоснование, переходные формы и инструментарий для тестирования в России» ${ }^{14}$ : эксперты разделились на примерно равные части относительно готовности России к введению ББД. При этом сторонники преимущественно выступают за переходные формы ББД, полагая, что на данном этапе наша страна не готова к полному инструментарию ББД [5]. Как показал опрос, наибольшая поддержка ББД (переходные формы) имеется среди экспертов

14 Основные итоги данного опроса представлены в дайджестах докладов Е. Одинцовой и Е. Черных. Подробнее об опросе экспертов и его результатах см. [5]. из числа научно-исследовательского сообщества (более $60 \%{ }^{15}$ ) и органов государственного и муниципального управления (около $60 \%$ ). Среди представителей ведущих ВУЗов доля сторонников ББД (переходные формы) ниже и составляет около $54 \%$. Бизнес-сообщество и профсоюзы в большей части выступают в пользу неготовности России к ББД (более $60 \%$ ). При этом практически всеми экспертами независимо от категории (от более 80 \% до $100 \%$ ) поддерживается целесообразность инструментария ББД в России для решения проблем бедности и обеспечения минимального уровня жизни уязвимых категорий населения.

Ещё одним важным шагом в этом направлении может стать реализация пилотных проектов для анализа возможных последствий и оценки результатов. Поддержка практической реализации инструментария ББД в пилотных проектах, как показал выше упоминавшийся опрос, уже имеется среди российского экспертного сообщества [5]. При этом поддержка есть среди всех категорий экспертов: научно-исследовательского сообщества (100\%), ведущих ВУЗов (более $80 \%)$, бизнес-сообщества и профсоюзов (более $70 \%$ ), органов государственного и муниципального управления (более $70 \%$ ). Академическим сообществом уже артикулированы возможные категории населения для реализации таких пилотных проектов, авторами предложены потенциальные схемы апробации инструментария ББД, проведено исследование реализуемости данных проектов с применением имитационного моделирования [4; 6; 7; и др.]. Проведение пилотных проектов, по мнению авторов, целесообразно для следующих наиболее уязвимых категорий населения: малоимущих семей с детьми; для выпускников профессиональных образовательных организаций, впервые выходящих на рынок труда; для работников с высокими рисками неустойчивой (прекаризованной) занятости, а также зарегистрированных безработных [5]. Необходимые наработки для реализации таких пилотных проектов в России имеются, дело - за политической волей.

Пандемия COVID-19 обострила данные проблемы, государство оказалось вынуждено вводить новые меры поддержки, столкнувшись с недостаточностью существующей системы социальных льгот и гарантий для решения масштабных проблем с занятостью и доходами россиян. В условиях пандемии реализация принципов ББД вышла на более значимый уровень. В России, как и в других странах, были реализованы принципы социальной помощи, обоснованные в концепции ББД - прежде всего, универсальность охвата и безусловность предоставления выплат $[5 ; 10]$.

\footnotetext{
15 Здесь и далее - в процентах от числа ответивших.
} 
Вместе с тем, концепция ББД в России на государственном уровне ещё не осознана, хотя пандемия внесла определенные подвижки в этом направлении, в том числе в изменении политического аспекта дискурса о введении ББД. Наряду с негативным отношением к идее ББД, сравнением его с «вертолётными» деньгами и пр. ${ }^{16}$, в 2020 г. на достаточно высоком уровне были озвучены предложения об обсуждении и введении ББД. Так, Заместителем Председателя Совета Безопасности Российской Федерации Д.А. Медведевым было предложено обсудить идею минимального гарантированного дохода граждан, при этом им была отмечена важность поддержки граждан для сохранения социальной стабильности ${ }^{17}$. Предложение ввести ББД для безработных было озвучено Председателем Комитета Совета Федерации по экономической политике А.В. Кутеповым ${ }^{18}$. Необходимость введения ББД поддержана Исполнительным Комитетом Союза профсоюзов России (СПР). ${ }^{19}$

Одной из российских парламентских фракций («Справедливая Россия») в 2021 г. анонсирована законодательная инициатива по установлению ежемесячной безусловной выплаты всем россиянам, финансирование которой предложено осуществлять из доходов от продажи углеводородов. ${ }^{20}$ Выплата должна покрывать основные потребности (питание, одежда, услуги, ЖКХ, культура). ${ }^{21}$ Данная инициатива является важным

16 Набиуллина снова выступила против «вертолётных» денег // Коммерсантъ. 28.12.2020. URL: https://www. kommersant.ru/doc/4636659 (дата обращения: 22.08.2021); Силуанов объяснил нежелание власти раздать населению «вертолётные деньги» // Ведомости. 06.05.2020. URL: https:// www.vedomosti.ru/economics/news/2020/05/06/829631 siluanov-obyasnil-nezhelanie (дата обращения: 22.08.2021).

17 Медведев предложил обсудить введение в России базового дохода // РБК, 08 сентября 2020. URL: https://www.rbc. ru/society/08/09/2020/5f57acbd9a7947fc9ba4d3c8 (дата обращения: 11.01.2021); Медведев предложил подумать о введении минимального гарантированного дохода // Ведомости, 08 сентября 2020. URL: https://www.vedomosti.ru/society/ news/2020/09/08/839213-medvedev-predlozhil-podumat-ovvedenii-dohoda (дата обращения: 11.01.2021).

18 В Совфеде предложили ввести дополнительное пособие для безработных // Российская газета, 07 сентября 2020. URL: https://rg.ru/2020/09/07/v-sovfede-predlozhili-vvesti-dopolnitelnoeposobie-dlia-bezrabotnyh.html (дата обращения: 11.01.2021); Медведев предложил обсудить введение в России базового дохода // РБК, 08 сентября 2020. URL: https://www.rbc.ru/society/08/09/2020 /5f57acbd9a7947fc9ba4d3c8 (дата обращения: 11.01.2021).

19 Решение Исполнительного Комитета Союза профсоюзов России (СПР) // Союз профсоюзов России. URL: http:// unionsrussia.ru/Activities/EventsInOrganizations/resheniyeispolnitelnogo-komiteta-soyuza-profsoyuzov-rossii (дата обращения 12.09.2021).

20 В Госдуму летом внесут законопроект о базовом доходе // TACC. 25.05.2021. URL: https://tass.ru/ekonomika/11469289 (дата обращения: 22.08.2021).

21 Сергей Миронов: Справедливый базовый доход - это инвестиции в человеческий капитал, которые вернутся сторицей. URL: https://spravedlivo.ru/11245810 (дата обращения: 22.08.2021). шагом в продвижении от обсуждения и осмысления концепции ББД на государственном уровне к её реализации в России.

В Германии ББД рассматривается как важная междисциплинарная тема, исследования которой вышли на новый уровень. Создан Фрайбургский Институт исследований базового дохода (FRIBIS), который объединяет не только учёных-экономистов и социологов, но и активистов, поддерживающих идеи ББД. Институт создан на средства Фонда Гётца Вернера, известного немецкого предпринимателя, ставшего одним из первых влиятельных популяризаторов концепции ББД в Германии. Г. Вернер представил впоследствии модель БД, финансируемого за счёт единого налога на потребление, который заменил бы большинство других налогов (подоходный налог, социальные отчисления и др.), таким образом, позволяя работникам сразу получить зарплату брутто, а также обозначил в дискуссии о ББД сумму в 1000 евро, которая многократно обсуждалась в дальнейшем.

Также в Германии успешно развёрнут и проводится пилотный проект «Безусловный базовый доход». Проект реализуется благодаря частным инвестициям (почти 200 тысяч человек финансово поддержали сбор), и первый этап будет проходить в течение трёх лет: 122 участника будут получать ББД, 1380 участников являются контрольной группой и не получают ББД. У этого проекта была предварительная фаза, менее научная, но более популярная, привлекшая общественный интерес к этому эксперименту.

Периодически выпускаются крупные исследования на тему расчётов схем ББД. Последнее такое исследование было проведено Институтом экономических исследований им. Лейбница в Мюнхене - с помощью нескольких микросимуляционных моделей оценивались некоторые экономические эффекты от введения четырёх разных схем ББД, в том числе просчитана стоимость их реализации с учётом вышеупомянутых эффектов. Работа, хотя она далеко не первая в своем роде, стала достаточно резонансной ввиду того, что результаты получились достаточно пессимистичными, и вызвала волну обсуждений, в частности, со стороны кандидата на пост канцлера Германии от социал-демократической партии Олафа Шольца. Сам Шольц признался, что не поддерживает идею БД как таковую, во-первых, потому что считает, что ББД в принципе невозможно финансировать, а во-вторых, потому что считает, что ББД противоречит принятым нормам морали. В своей предвыборной программе Шольц говорит о том, что собирается в течение года принять все необходимые меры для того, чтобы поднять МРОТ до 12 евро 
в час повсеместно, считая это более справедливой мерой социальной защиты. Социал-демократическая партия на сегодняшний день против концепции ББД, аргументируя это приверженностью традиционным нормам относительно необходимости работы в обществе и важности самоидентификации посредством реализации себя в трудовых отношениях. Социал-демократы планируют реформы системы социальной поддержки, основанные на более либеральных принципах её получения.

В программах других популярных кандидатов и партий на сегодняшний день предложений конкретного внедрения ББД нет: максимально приближенные к ББД предложения - у партии «Левые» и коалиции «Зелёных». Программы некоторых других партий, например, «Свободной демократической партии», содержат элементы, которые можно рассматривать как переходные формы ББД, хотя некоторые из партий открыто против ББД. Союз ХДС/ХCС пока что также не поддерживает полностью идею внедрения ББД, предпочитая, как и социал-демократы, работу над текущими мерами социальной поддержки: например, снижение бюрократизированности процесса получения пособий. Обосновываются такие идеи в первую очередь необходимостью целенаправленно возвращать граждан на рынок труда: девизом реформ является «требовать и поддерживать». Однако, несмотря на разные взгляды на проблематику систем социальной поддержки, у большинства партий присутствуют элементы обеспечения некоторых групп населения «базовым» доходом. Так, например, базовая пенсия - концепция ХДС/ХСС, у «Зелёных» - базовый доход за счёт «климатических» налогов и др.

В целом, учёные считают, что, несмотря на относительно слабую или неоднозначную поддержку со стороны политиков, на сегодняшний день, концепция ББД является единственно возможной основой организации систем социальной защиты в будущем. Переход к универсальному базовому доходу возможно осуществить только постепенно, посредством переходных форм. Таким образом, регулярное проведение научных конференций и исследований крайне важно для развития в этом направлении.

О необходимости расширения экспериментальной практики введения ББД говорилось и на прошедшем в августе 2021 г. масштабном Конгрессе BIEN. Наряду со страновыми практиками на Конгрессе обсуждалась идея перехода от небольших экспериментов к более масштабному, комплексному, долгосрочному пилотированию ББД, а также возможные стратегии реализации такого пилотирования для местного, субнационального, национального и транснационального уровней. ${ }^{22}$

\section{Заключение}

Международная научная конференция «Безусловный базовый доход как регулятор повышения уровня и качества жизни граждан и устойчивости общества: проблемы и возможные пути их решения», состоявшаяся в 2021 г. в РЭУ им. Г.В. Плеханова, стала важной дискуссионной «площадкой» для развития исследований проблематики ББД, способствовав продвижению к более согласованной позиции относительно методологических и практических аспектов концепции ББД. В рамках конференции были предложены и обсуждены возможные направления пилотной апробации инструментария ББД в России. Гипотеза исследования подтвердилась. Материалы международной конференции очерчивают основные проблемные контуры исследования концепции ББД и вопросов её внедрения, позволяя определить направления дальнейших разработок, среди важнейших из которых - поиск целесообразных страновых переходных форм ББД и инструментариев его экспериментальной апробации для повышения уровня и качества жизни и устойчивости общества. Исследователи видят в ББД универсальный инструмент для решения социальных проблем в любой стране, с любым уровнем благосостояния населения, вне зависимости от политического устройства или каких-либо других факторов.

\section{Благодарность и финансирование}

Исследование выполнено при финансовой поддержке РФФИ в рамках научного проекта №20-010-00271.

${ }^{22}$ Basic Income Earth Network Congress 2021. URL: https://cbin.scot/bien2021/ (Accessed: 23.08.2021); Basic Income in Turkey and Russia. Basic Income Earth Network Congress 2021. URL: https://whova.com/embedded/session/ bienc_202108/1841054/?view= (Accessed: 23.08.2021); From idea to reality in Greece, Italy and Slovenia. Basic Income Earth Network Congress 2021. URL: https://whova.com/ embedded/session/bienc_202108/1841070/?view= (Accessed: 23.08.2021); Funding models for Basic Income in Germany, South Korea and Switzerland. Basic Income Earth Network Congress 2021. URL: https://whova.com/embedded/session/ bienc_202108/1841074/?view= (Accessed: 23.08.2021); From idea to reality in Netherlands, Portugal and for the whole of Europe. Basic Income Earth Network Congress 2021. URL: https://whova. com/embedded/session/bienc_202108/1841107/?view= $\quad($ Accessed: 23.08.2021); How to move from the unambitious smallsized UBI experiments to massive UBI programs in EU/rope Global Inspiration, Strategies, Ideas, Experiences, Criticism, Collaboration Invitations, Objectives of UBC etc. Basic Income Earth Network Congress 2021. URL: https://whova.com/ embedded/session/bienc_202108/1841127/?view= (Accessed: 23.08.2021); и др. 


\section{Список литературы}

1. Андреенкова А.В. Сравнительный анализ отношения населения к идее безусловного базового дохода в России и в Европе // Социологические исследования. 2020. №1. С. 18-30. DOI: 10.31857/S013216250008321-6.

2. Антипов В.И., Митин Н.И., Пащенко Ф.Ф. Модифицированная макроэкономическая имитационная модель развития России // Препринты ИПМ им. М.В. Келдыша. 2018. №272. 36 с.

3. Бобков В.Н., Долгушкин Н.К., Одинцова Е.В. Безусловный базовый доход: размышления о возможном влиянии на повышение уровня и качества жизни и устойчивости общества // Уровень жизни населения регионов России. 2019. Том 15. №3. C. 8-24. DOI: 10.24411/1999-9836-2019-10069.

4. Бобков В.Н., Антипов В.И., Колмаков И.Б., Черных Е.А. Моделирование сценариев преодоления абсолютной монетарной бедности в России на основе концепции безусловного базового дохода // Уровень жизни населения регионов России. 2021. №2. C. 204-215. DOI: https://doi.org/10.19181/lsprr.2021.17.2.4.

5. Бобков В.Н., Одинцова Е.В. Российские эксперты о безусловном базовом доходе: оценки 2020 г. // Уровень жизни населения регионов России. 2021. №1. C. 67-86. DOI: 10.19181/lsprr.2021.17.1.6.

6. Бобков В.Н., Антипов В.И., Колмаков И.Б., Павлова В.В. Переходные формы безусловного базового дохода и варианты инструментария для тестирования в России на примере безработных // Вестник Российского экономического университета им. Г.В. Плеханова. 2020. Том 17. №5. С. 69-84. DOI: 10.21686/2413-2829-2020-5-69-84.

7. Бобков В.Н., Гулюгина А.А., Одинцова Е.В. Методологические подходы к усилению адресности социальной поддержки малоимущих семей с детьми // Уровень жизни населения регионов России. 2019. №1. С. 9-19. DOI: 10.24411/1999-9836-2019-10049. 8. Волков А. Теория и практика базового дохода в ряде северных стран // Мировая экономика и международные отношения. 2020. Том 64. №9. С. 48-52. DOI: 10.20542/0131-2227-2020-64-9-48-52.

9. Гонтмахер Е. Базовый доход: пролог к социальной политике XXI века? // Экономическая политика. 2019. № 2. С. $156-177$. DOI: $10.18288 / 1994-5124-2019-2-156-177$.

10. Золотов А.В., Золотов С.А. Реализация принципов безусловного базового дохода как ответ на вызовы коронавируса // Уровень жизни населения регионов России. 2020. №4. С. 96-104. DOI: https://doi.org/10.19181/lsprr.2020.16.4.8.

11. Капелюшников Р.И. Универсальный базовый доход: есть ли у него будущее? М.: Изд. Дом Высшей школы экономики, 2020. 52 с.

12. Кислищына О.А. Введение системы безусловного базового дохода: что думают россияне? кто «за», кто «против»? // Вестник Института экономики Российской академии наук. 2019. №3. С. 32-47. DOI: 10.24411/2073-6487-2019-10030.

13. Трофимов О.В., Золотов С.А., Ежов А.С. Режим труда как мотиватор трудовой деятельности рабочих на примере предприятия пищевой промышленности // Вестник Нижегородского университета им. Н.И. Лобачевского. Серия: Социальные науки. 2020. №3 (59). С. 32-39.

14. Черных Е.A. Современное состояние исследований содержания, форм, инструментов и механизмов введения безусловного базового дохода // Уровень жизни населения регионов России. 2020. №2. С. 61-75. DOI: 10.19181/lsprr/2020.16.2.6. 15. Althaus D. Das Solidarische Bürgergeld Sicherheit und Freiheit ermöglichen Marktwirtschaft // Das Solidarische Bürgergeld. De Gruyter Oldenbourg. 2016. P. 1-12.

16. Bach S., Isaak N., Kemfert C., Kunert U., Schill W. P., Wägner N., Zaklan A. Für eine sozialverträgliche CO2-Bepreisung. DIW Berlin: Politikberatung kompakt. 2019. No. 138. 34 p.

17. Das Konzept eines deutschen Bürgerfonds / C. Fuest, C. Hainz, V. Meier, M. Werding. München: ifo Institut. 2019.31 p.

18. Gentilini U., Grosh M., Rigolini J., Yemtsov R. Exploring Universal Basic Income: A Guide to Navigating Concepts, Evidence, and Practices. Washington: World Bank. 2020. 312 p. DOI: 10.1596/978-1-4648-1458-7.

19. Haagh L. The Case for Universal Basic Income. John Wiley and Sons. 2019. 140 p.

20. Kangas O., Jauhiainen S., Simanainen M., Ylikännö M. The Basic Income Experiment 2017-2018 in Finland. Preliminary results. Reports and Memorandums of the Ministry of Social Affairs and Health 2019:9. Helsinki: Ministry of Social Affairs and Health. 2019.30 p. 21. Martinelli L. Exploring the distributional and work incentive effects of plausible illustrative Basic Income schemes. Bath: Institute for Policy Research, University of Bath. 2017.67 p.

22. Opielka M. (Ed.). Grundrente in Deutschland: Sozialpolitische Analysen. Springer-Verlag. 2013. Vol. 6. 272 p.

23. Rawls J. A Theory of Justice. Cambridge, Massachusetts. London: Harvard University Press. 1971. 607 p. DOI: 10.2307/j.ctvjf9z6v.

24. Standing G. Basic Income: And How We Can Make It Happen. London: Penguin. 2017. 400 p.

25. Standing G. Battling eight giants: Basic income now. Bloomsbury Publishing. 2020. 152 p.

26. Van Parijs P. Basic income: a simple and powerful idea for the 21 st century // Politics\&Society. 2004. Vol. 32. No. 1. P. 7-39.

27. Widerquist K. A critical analysis of basic income experiments for researchers, policymakers, and citizens. Springer International Publishing, 2018. 167 p. DOI: 10.1007/978-3-030-03849-6.

28. Zelleke A. Institutionalizing the universal caretaker through a basic income? // Basic Income Studies. 2008. Vol. 3. No. 3. DOI: 10.2202/19320183.1133 .

\section{Заявленный вклад авторов:}

Бобков В.Н. - общий замысел статьи, введение, обзор позиций российских и зарубежных участников конференции, дискуссия, заключение. Одинцова Е.В. - общий замысел статьи, введение, обзор позиций российских участников конференции, дискуссия, заключение. Пилюс А.Г. - обзор позиций зарубежных участников конференции, дискуссия.

\section{Сведения об авторах:}

Вячеслав Николаевич Бобков - доктор экономических наук, профессор, заслуженный деятель науки РФ, заведующий лабораторией проблем уровня и качества жизни ИСЭПН ФНИСЦ РАН, директор Научного центра экономики труда РЭУ им. Г.В. Плеханова. E-mail bobkovvn@mail.ru elibrary AuthorID 275902

ORCID ID https://orcid.org/0000-0001-7364-5297 ResearchID U-6527-2019

Елена Валерьевна Одинцова - кандидат экономических наук, ведущий научный сотрудник лаборатории проблем уровня и качества жизни ИСЭПН ФНИСЦ РАН, ведущий научный сотрудник Научного центра экономики труда РЭУ им. Г.В. Плеханова. E-mail odin_ev@mail.ru elibrary AuthorID 999153

ORCID ID https://orcid.org/0000-0002-7906-8520 ResearchID U-7061-2019

Александра Глебовна Пилюс - аспирант кафедры экономической политики и конституционной экономики им. Гётца Вернера Фрайбургского Университета им. Альберта и Людвига, научный сотрудник Фрайбургского Института исследований базового дохода. E-mail alexandra.pilyus@jupiter.uni-freiburg.de elibrary AuthorID 1120838

ORCID ID https://orcid.org/0000-0002-8440-2896 ResearcherID AAX-6332-2021 


\title{
UNIVERSAL BASIC INCOME AS A REGULATOR OF INCREASING THE STANDARD AND QUALITY OF LIFE OF CITIZENS AND SOCIETY SUSTAINABILITY: PROBLEMS AND POSSIBLE WAYS OF THEIR SOLUTION. \\ Discussion at the Russian-German international conference. Moscow. May 20, 2021
}

\section{RAR (Research Article)}

Recieved: 14.09.2021 Accepted: 13.10.2021 Published: 03.12.2021

For citation: Bobkov V.N., Odintsova E.V., Pilyus A.G. Universal basic income as a regulator of increasing the standard and quality of life of citizens and society sustainability: problems and possible ways of their solution. Discussion at the Russian-German international conference. Moscow. May 20, 2021. Living Standards of the Population in the Regions of Russia. 2021. Vol. 17. No.4. P. 524-541. DOI: 10.19181/lsprr.2021.17.4.9

\author{
VYACHESLAV N. BOBKOV ${ }^{1,2}$, ELENA V. ODINTSOVA ${ }^{1,2}$, ALEXANDRA G. PILYUS $^{3}$ \\ ${ }^{1}$ ISESP FCTAS RAS (32 Nakhimovsky prospect, Moscow, Russian Federation, 117218). \\ 2 Plekhanov Russian University of Economics (36 Stremyanny lane, Moscow, Russian Federation, 117997). \\ ${ }^{3}$ Albert-Ludwigs-University of Freiburg (Fahnenbergplatz, Freiburg im Breisgau, Germany, 79085).
}

\begin{abstract}
This paper examines international discourse borders regarding theoretical and practical problems of Universal basic income concept through the prism of the scientific discussion which took place in May 2021 at the International Scientific Russian-German Conference «Universal basic income as a regulatory measure for improvement of citizens' standard and quality of life improvement and social sustainability: problems and possible solutions». The authors presented the digests of the speakers' speeches, which formed the scientific basis of the article devoted to the conceptualization of the phenomenon of universal basic income (UBI), scientific, political, and state aspects of the discourse on the implementation of UBI, the problems of introduction of UBI in transitional forms, the practice of the experimental introduction of $\mathrm{UBI}$, modeling the consequences of the introduction of UBI, the impact of UBI on various aspects of life, etc. The materials of the above-mentioned Conference depict the main problematic edges of UBI concept exploration as well as implementation issues and allow to determine directions of further appliances. The most important ones are - search for country-specific transitional forms of UBI and instruments for its experimental approbation in order to improve quality of life and social sustainability of the society. The discussion at the Conference about the UBI concept is commented in the paper in the context of factual actions of Russian and German officials, ideas and suggestions of the international scientific community, and the need for a transition towards greater and complex UBI piloting, considering aspects examined in detail at the International BIEN Congress (August 2021), Glasgow, Scotland.
\end{abstract}

Keywords: universal basic income, transitional forms, pilot projects, standard of living, quality of life, sustainability of society, scientific discourse

Acknowledgements. The reported study was funded by RFBR, project number 20-010-00271.

\section{References}

1. Andreenkova A.V. A Comparative Analysis of Popular Attitudes toward the Idea of Universal Basic Income in Russia vs Europe. Sociological Studies. 2020. No. 1. P. 18-30 DOI: 10.31857/S013216250008321-6 (In Russ.).

2. Antipov V.I., Mitin N.I., Pashchenko F.F. Modified macroeconomic simulation model of Russia's development. Preprinty IPM im. M.V. Keldysha [Preprints of the IPM named after M. V. Keldysh]. 2018. No. 272. 36 p. (In Russ.).

3. Bobkov V.N., Dolgushkin N.K., Odintsova Y.V. Universal Basic Income: Reflections on the Possible Impact on Improving the Living Standards and Quality of Life and the Sustainability of Society. Living Standards of the Population in the Regions of Russia. 2019. Vol. 15. No. 3. P. 8-24. DOI: 10.24411/1999-9836-2019-10069 (In Russ.).

4. Bobkov V.N., Antipov V.I., Kolmakov I.B., Chernykh E.A. Simulation of scenarios for overcoming absolute monetary poverty in Russia based on the concept of unconditional basic income. Living Standards of the Population in the Regions of Russia. 2021. Vol. 17. No. 2. P. 204-215. DOI: 10.19181/lsprr.2021.17.2.4 (In Russ.).

5. Bobkov V.N., Odintsova Y.V. Russian Experts on Universal Basic Income: Estimates for 2020. Living Standards of the Population in the Regions of Russia. 2021. Vol. 17. No. 1. P. 67-86. DOI: 10.19181/lsprr.2021.17.1.6 (In Russ.).

6. Bobkov V.N., Antipov V.I., Kolmakov I.B., Pavlova V.V. Transitional Forms of Universal Basic Income and Options of Testing Tools in Russia, Illustrated by Unemployed. Vestnik of the Plekhanov Russian University of Economics. 2020. Vol. 17. No. 5. P. 69-84. DOI: 10.21686/2413-2829-2020-5-69-84 (In Russ.).

7. Bobkov V.N., Gulyugina A.A., Odintsova Y.V. Methodological Approaches to Strengthening Addressed Social Supporting Indigent Families with Children. Living Standards of the Population in the Regions of Russia. 2019. Vol. 15. No. 1. P. 9-19. DOI: 10.24411/1999-9836-2019-10049 (In Russ.).

8. Volkov A. Basic Income in Some Nordic Countries: Theory and Practice. World economy and international relations. 2020. Vol. 64. No 9. P. 48-52. DOI: 10.20542/0131-2227-2020-64-9-48-52 (In Russ.)

9. Gontmacher E. Basic income: a prologue to the social policy of the XXI century? Economic policy. 2019. No. 2. P. 156-177. DOI: 10.18288/1994-5124-2019-2-156-177 (In Russ.).

10. Zolotov A.V., Zolotov S.A. Realization of the UBI Principles As An Answer to the COVID-19 Challenges. Living Standards of the Population in the Regions of Russia. 2020. Vol. 16. No. 4. P. 96-104. DOI: 10.19181/lsprr.2020.16.4.8 (In Russ.).

11. Kapelyushnikov R.I. Universal'nyj bazovyj dohod: est' li u nego budushchee? [Universal basic income: does it have a future?] Moscow: Ed. House of the Higher School of Economics, 2020. 52 p. (In Russ.).

12. Kislitsyna O.A. Introduction of the unconditional basic income system: what do Russians think about it? who is for, who is against? Bulletin of the Institute of Economics of the Russian Academy of Sciences. 2019. No. 3. P. 32-47. DOI: 10.24411/2073-64872019-10030 (In Russ.). 
13. Trofimov O.V., Zolotov S.A., Ezhov A.S. Working schedule as a labor activity motivator for food industry workers. Bulletin of the Nizhny Novgorod University named after N.I. Lobachevsky. Series: Social Sciences. 2020. No. 3 (59). P. 32-39. (In Russ.).

14. Chernykh Y.A. The Current State of Research of the Content, Forms, Tools and Mechanisms of Introducing Unconditional Basic Income. Living Standards of the Population in the Regions of Russia. 2020. Vol. 16. No. 2. P. 61-75. DOI: 10.19181/1sprr/2020.16.2.6 (In Russ.).

15. Althaus D. Das Solidarische Bürgergeld Sicherheit und Freiheit ermöglichen Marktwirtschaft. Das Solidarische Bürgergeld. De Gruyter Oldenbourg. 2016. P. 1-12.

16. Bach S., Isaak N., Kemfert C., Kunert U., Schill W. P., Wägner N., Zaklan A. Für eine sozialverträgliche CO2-Bepreisung. DIW Berlin: Politikberatung kompakt. 2019. No. 138. 34 p.

17. Das Konzept eines deutschen Bürgerfonds. C. Fuest, C. Hainz, V. Meier, M. Werding. München: ifo Institut. 2019.31 p.

18. Gentilini U., Grosh M., Rigolini J., Yemtsov R. Exploring Universal Basic Income: A Guide to Navigating Concepts, Evidence, and Practices. Washington: World Bank. 2020. 312 p. DOI: 10.1596/978-1-4648-1458-7.

19. Haagh L. The Case for Universal Basic Income. John Wiley and Sons. 2019. 140 p.

20. Kangas O., Jauhiainen S., Simanainen M., Ylikännö M. The Basic Income Experiment 2017-2018 in Finland. Preliminary results. Reports and Memorandums of the Ministry of Social Affairs and Health 2019:9. Helsinki: Ministry of Social Affairs and Health. 2019. $30 \mathrm{p}$.

21. Martinelli L. Exploring the distributional and work incentive effects of plausible illustrative Basic Income schemes. Bath: Institute for Policy Research, University of Bath. 2017.67 p.

22. Opielka M. (Ed.). Grundrente in Deutschland: Sozialpolitische Analysen. Springer-Verlag. 2013. Vol. 6. 272 p.

23. Rawls J. A Theory of Justice. Cambridge, Massachusetts; London: Harvard University Press. 1971. 607 p. DOI:10.2307/j. ctvjf9z6v

24. Standing G. Basic Income: And How We Can Make It Happen. London: Penguin. 2017. 400 p.

25. Standing G. Battling eight giants: Basic income now. Bloomsbury Publishing. 2020. 152 p.

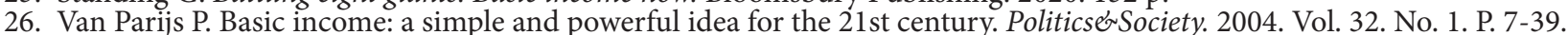

27. Widerquist K. A critical analysis of basic income experiments for researchers, policymakers, and citizens. Springer International Publishing, 2018. 167 p. DOI: 10.1007/978-3-030-03849-6.

28. Zelleke A. Institutionalizing the universal caretaker through a basic income? Basic Income Studies. 2008. Vol. 3. No. 3. DOI: 10.2202/1932-0183.1133.

\section{Authors' declared contribution:}

Vyacheslav N. Bobkov - the general concept of the article, introduction, review of the positions of the Russian and foreign participants of the conference, discussion, conclusion.

Elena V. Odintsova - the general concept of the article, introduction, review of the positions of the Russian participants of the conference, discussion, conclusion.

Alexandra G. Pilyus - review of the positions of foreign participants of the conference, discussion.

\section{Information about the authors:}

Vyacheslav N. Bobkov - Doctor of Economics, Professor, Honoured Science Worker of the Russian Federation, Head of the Laboratory of Problems of Living Standards and Quality of Life at the ISESP FCTAS RAS; Director of the Scientific Center of Labor Economics at Plekhanov Russian University of Economics.

E-mail bobkovvn@mail.ru elibrary AuthorID 275902

ORCID ID https://orcid.org/0000-0001-7364-5297 ResearchID U-6527-2019

Elena V. Odintsova - PhD in Economics, Leading Research Worker of the Laboratory of Problems of Living Standards and Quality of Life at the ISESP FCTAS RAS; Leading Research Worker of the Scientific Center of Labor Economics at Plekhanov Russian University of Economics.

E-mail odin_ev@mail.ru elibrary AuthorID 999153

ORCID ID https://orcid.org/0000-0002-7906-8520 ResearchID U-7061-2019

Alexandra G. Pilyus - PhD Candidate, Götz Werner Chair for Economic Policy and Constitutional Economics; Research fellow at FRIBIS Freiburg Institute for Basic Income Studies; Albert Ludwig University of Freiburg.

E-mail alexandra.pilyus@jupiter.uni-freiburg.de elibrary AuthorID 1120838

ORCID ID https://orcid.org/0000-0002-8440-2896 ResearcherID AAX-6332-2021

The author responsible for the correspondence is Elena V. Odintsova 